\title{
THE ROLE OF RELIGION IN PREVENTING CRIME IN RISK SOCIETY SPECIFIC TO GLOBALIZATION
}

\author{
R. G. Paraschiv
}

\author{
Ramona-Gabriela Paraschiv \\ Faculty of Law, \\ "Dimitrie Cantemir" Christian University, Bucharest, Romania \\ *Correspondence: Ramona-Gabriela Paraschiv, 30 General Magheru St., Râmnicu Vâlcea, \\ Vâlcea, Romania \\ E-mail: ramonaparaschiv@ rocketmail.com
}

Abstract

In the current context of increasing transnational organized crime, in a risk society favored by certain phenomena of individualism and globalization, it is necessary to investigate what role the Church may have in preventing deeds dangerous to human values.

In this respect, the Romanian Orthodox Church, which has a well-defined place in the new European construction, aims to substantially contribute to educating people in the spirit of Christian morality, so that they cannot commit antisocial acts injurious to others and for other values of humanity.

Keywords: rules of conduct, religion, crime, prevention, morality

\section{Introduction}

Based on the research of statistics and facts of reality, we conclude that, once Romania entered the European Union, globalization in general, cross-border crime numbers increased, but also the seriousness of the offenses committed, which requires enhancing legislative measures and organization of judicial institutions of the state and finding the most effective action methods of preventing crime.

Along with the guarantees provided by state laws, which are intended to establish the rule of law, spiritual warranty is felt more strongly, arising from faith, with hope that the future of humanity will be enlightened by a new Christian humanism ${ }^{I}$.

The Church's role in educating people to prevent anti-social acts in the context of European integration

At the beginning of the third millennium, the development of social phenomena is constantly accelerating, causing great changes in science and material progress, but also in the sphere of philosophical concepts, morality and faith, which generates new patterns of behavior and other scales of values in a human society dominated by individualism risks, with all its negative consequences, but also globalization risks, which facilitates the unprecedented development of various forms of transnational crime, with particularly high risks for human safety, which is likely to lead to the establishment of feelings of fear, hopelessness and mistrust in the future - all leading to human alienation.

Scientific progress, in the context of cross-border freedom of movement, allows not only to improve quality of life physically and spiritually, but also involves the risk of using

\footnotetext{
1 W. Dancă, Dialog Teologic, in the magazine "Mitropolia Olteniei", Year LVIII no. 5-8/2006, "Editura Mitropolia Olteniei" Publishing House, Craiova, 2006, p. 134, showing that the future will remain a period of people who are beginning to rediscover the depth of the spiritual life and the greatness of the universe, but must continue pleading for an ideal and a constitutive reference for a moral guidance, because, if that did not exist, the world would turn to chaos of desires and a worrying manifestation of lack of love.
} 
this development results in a negative, harmful way to humans, from this benefiting organized crime, terrorism, drugs, human trafficking and exploitation of children, fraud and corruption, currency counterfeiting, money laundering, cyber-crime, environmental degradation, racism and xenophobia, genocide, crimes against humanity and war crimes ${ }^{2}$.

Law states, with a consolidated democracy, try to promote the best legislative measures to effectively fight against those who commit such acts, and the European Union has promptly developed numerous rules and regulations against these criminal phenomena affecting human values, mobilizing the efforts of Member States in order to effectively fight against crime and perseverance ${ }^{3}$.

Despite all legislative measures taken to streamline the activity of repressive judicial bodies, crime is still growing, registering ever more victims, and on the other hand, many people with criminal records, which is a major risk for the development of society in terms of morality, so if there are no other solutions to reduce crime, it is possible that life and other values of future generations will become more threatened.

The state, through its bodies, edicts laws and sanctions those who violate them, but due to objective or subjective factors, many of the antisocial acts that contravene not only the laws but also religious norms, which in many cases are the source of legal norms, remain unsanctioned, their authors being encouraged to continue the same criminal behavior.

But the purpose of any civilized society would be, first, not to commit antisocial acts, not to be happy that there are more people convicted and thus a correlative number of victims. As a result, the solution would be, mainly, educating people to respect the others, the social and human values accepted both by religion, as well as societies with a genuine democracy.

How states that have many concerns in terms of improving people's behavior, which they exercise through their bodies, do not put special emphasis on educating people to respect the rules of conduct, but is organized primarily for taking action against those who violate them, we consider that the church's role in guiding people towards a moral behavior must be growing stronger. Therefore, first we must act against the individualism that is the enemy, increasing the distances between people, which it divides, and promotes human focus exclusively on his own person, thus giving birth to monsters ${ }^{4}$.

With reference to the current situation in Romania, it is noted that, if before the fall of communism in December 1989, the rule of law was referred to, generally by repressive means, the population having a sense of fear, nowadays freedom has been misunderstood by most people who have a retrograde conscience and who have not acquired a deep healthy morality, therefore trying to stand out by fraudulent activities that lead to their unjustified enrichment, or by acts of violence, promoting anarchic attitude. All these are likely to affect the morality and the operation of the fragile rule of law, questionable people being promoted often as role models, lacking culture and virtue, which makes young people to be confused in choosing their way of life, from lack of valuable criteria and authentic models.

In such circumstances, the Church, religious morality should play an important role in bringing people towards good and what is right, thus contributing to the restoration of genuine valuable criteria and convincing the young generation to follow real valuable models.

The fall of the communist regime created the possibility of church administrative restoration, among them, the reorganization, re-establishment and creation of 14 dioceses in the Romanian Patriarchate and the introduction of religious education in schools, the reintegration of theological education into the state university etc.

\footnotetext{
${ }^{2}$ G. Paraschiv, Drept penal al Uniunii Europene, "C.H. Beck” Publishing House, Bucharest, 2008, p. 26.

${ }^{3}$ G. Antoniu, Activitatea normativă penală a Uniunii Europene, in "Revista de drept penal” Review, Year XIV No. 3/2007, pp. 1-2.

${ }^{4}$ V. Citirigă, Rădăcinile individualismului şi implicațiile lui din punct de vedere ortodox, in "Ortodoxia" Review, magazine of the Romanian Patriarchy, Series II, Year I, no. 11, Bucharest, April-June 2009, pp. 160162.
} 
These measures provide a stronger church presence in social life, thus contributing to educating people in the sense of moral compliance, to ensure normal relations of coexistence, without the need to commit antisocial acts.

Many Romanian Orthodox people, especially the new generation, look to the European Union with hope as being a chance for a better future for their country as normal for a continent too often divided religiously and politically, integration having the following reasons:

- To overcome the economic crisis facing the country, we need external support;

- Fast implementation of democracy and social development requires cooperation with developed countries of Europe;

- National security, scientific, spiritual and material progress also require cooperation with advanced countries in the European area;

- National culture should not be isolated but to enter the continental and universal circuit;

- Common Christian witness and contribution of religious communities to human life, nationally and internationally, are more likely to succeed in a united Europe than in a divided Europe.

Together with the Orthodox-majority countries: Greece and Cyprus, which together include about 11 million Orthodox people, in 2007 Romania joined the European Union (18800 Orthodox people of the total population of 21700) and Bulgaria (6 200 Orthodox people of the total population of 7450) therefore over 25 million Orthodox people were added to the existing 11 million in the Union ${ }^{6}$.

Romania's EU integration also raises the question whether our country's Orthodox theology is compatible with the Christian community and whether it can actually help to maintain social order.

The Romanian Orthodox Church has supported and helped by specific means the integration of Romania into the European Union in order to achieve the goal of a better collaboration with advanced European countries, for the purpose of the economic development of the country, with the consequence of increasing living standards, but also able to establish a genuine rule of law, where people's rights and freedoms are guaranteed and protected, states being able to better defend themselves against antisocial acts.

European unity cannot be achieved, actually, only on economic basis, but it must rediscover common spiritual dimension, and in this field Romanian Orthodox people can bring, in a dialogue without complexes and without aggression, its experience of people crucified and risen from the dead ten times in its history, by placing it among the most religious people of Europe ${ }^{7}$.

Over time, it was found that, in addition to the political-economic dimension of EU states, there is a focus on the cultural and spiritual component, which led the European Parliament to adopt, in December 1997, with a budget reference "A Soul for Europe" for the development of this social foundation, in which religion plays an important role in establishing a common European identity and to educate people in the spirit of defending the values of humanity, against antisocial acts.

Since in our country, in communist times, duplicity and form without substance have been promoted in excess, influencing people to deal with shallowness social and Christian moral values, which led many to the commission of many antisocial acts, it is necessary that the church, through its representatives, to bring the consciousness of all genuine values, to make them deepen into the social and ethical phenomena, because even towards religious morality some people show only a formal interest, seeing religion only as "something" that

\footnotetext{
${ }^{5}$ M. Răduț Selişte, The Romanian Orthodox Church and the New Europe, on http://www.rostonline.org/rost/ian2006/bor.shtml (accessed on September 6, 2011).

${ }^{6}$ M. Răduț Seliște, op. cit.

7 A. Gabor, R. P. Mureşan, Biserica Ortodoxă în UE, “Editura Universității din Bucureşti” Publishing House, Bucharest, 2006, p. 119.
} 
must solve their material problems, without making efforts in good faith. Also, there is still a damaging opinion that those who commit antisocial acts can be forgiven of all sins, no matter how bad they are, even when the acts committed are identified with serious crimes provided by criminal law, therefore not having any serious concern to correct their conduct for meeting social order, hoping that they can escape from divine judgment and the judicial courts of the state.

European unity cannot be achieved, actually, only on economic basis, but it must rediscover common spiritual dimension, and in this field Romanian Orthodox people can bring, in a dialogue without complexes and without aggression, its experience of people crucified and risen from the dead ten times in its history, by placing it among the most religious people of Europe ${ }^{8}$.

Over time, it was found that, in addition to the political-economic dimension of EU states, there is a focus on the cultural and spiritual component, which led the European Parliament to adopt, in December 1997, with a budget reference "A Soul for Europe" for the development of this social foundation, in which religion plays an important role in establishing a common European identity and to educate people in the spirit of defending the values of humanity, against antisocial acts.

\section{Conclusions}

The integration process of the Church in the European Union is not a goal in itself but is meant to contribute to the cultural and spiritual development of people, to the enrichment of the knowledge about life and how it should be lived. The Church representatives are opinion makers who can contribute directly to increasing public awareness regarding the advantages and disadvantages, costs and benefits of accession, while also having an important role in training people to meet human values and not to commit antisocial acts of harmful nature.

Romanian Orthodox spirituality will be required in the great family of European states, with a specific identity, which professes Eastern faith in a language of Western origin and which may constitute a bridge between East and West, as Orthodoxy has developed a Church as a means to maintain a balance between the spiritual and social element ${ }^{9}$ of Christian life, contributing substantially to educate people in order to respect the rules of conduct imposed by society and religion.

\section{Bibliography}

V. Citirigă, Rădăcinile individualismului şi implicațiile lui din punct de vedere ortodox in "Ortodoxia" Review, magazine of the Romanian Patriarchy, Series II, Year I, no. 11, Bucharest, April-June 2009;

G. Paraschiv, Drept penal al Uniunii Europene, "C.H. Beck" Publishing House, Bucharest, 2008;

G. Antoniu, Activitatea normativă penală a Uniunii Europene, in "Revista de drept penal" Review, Year XIV Nr. 3/2007;

W. Dancă, Dialog Teologic, in the "Mitropolia Olteniei" Review, Year LVIII no. 58/2006, Metropolitan Church of Oltenia Publishing House, Craiova, 2006;

A. Gabor, R. P. Mureşan, Biserica Ortodoxă în Uniunea Europeană, "Editura Universităţii din Bucureşti” Publishing House, Bucharest, 2006;

A. Plămădeală, Antonie, Biserica slujitoare, Sibiu, 1986;

http://www.rostonline.org/rost/ian2006/bor.shtml.

\footnotetext{
${ }^{8}$ A. Gabor, R. P. Mureşan, Biserica Ortodoxă in Uniunea Europeană, "Editura Universității din Bucureşti” Publishing House, Bucharest, 2006, p. 117.

${ }^{9}$ A. Plămădeală, Antonie, Biserica slujitoare, Sibiu, 1986, p. 204.
} 